\title{
Development of a Parent Engagement Learning Model Through Suggestion Box and a Corner of Pouring of Students Heart in Public Junior School at Binjai
}

\author{
Lenni Arta FS. Sinaga \\ Post Graduate Students of \\ Universitas Negeri Medan, \\ North Sumatra, Indonesia
}

\author{
Paningkat Siburian \\ Professor at Universitas \\ Negeri Medan \\ North Sumatra, Indonesia
}

\author{
Sukarman Purba \\ Lecturer at Universitas \\ Negeri Medan \\ North Sumatra, Indonesia
}

\author{
Panigoran Siburian \\ Lecturer at Universitas \\ Prima Medan \\ North Sumatra, Indonesia
}

\begin{abstract}
This study aims to determine the effectiveness of the partnership model of parents through the vent in the corner box Binjai City Junior High School; found output partnership model parents through town and corner confide in SMP Negeri Binjai city; determine the responses of managers (principals, teacher / homeroom / teacher BK) as the Parent Partnership Model in SMP Negeri Binjai city; and know factors that influence childrens learning in the comfort of frame development partnership model parents in SMP Negeri Binjai city. The research method is a research and development approach. To determine the activeness level model was used t-test and process data analysis using SPSS application assistance. The result of the research found that: a) the partnership model parents in SMP Negeri Binjai city is categorized effective. From the analysis of the effectiveness of the model by using paired sample t-test that all variables have value change of significance (2-tailed) is 0.000 (below 0.05), which means all the variables change significantly after being given treatment, increase parent support for the implementation of family education both at home and at school; d) and contention manager (principal, teacher/homeroom/teacher BK) as the Model Partnership Parents through the box and Corner very important to be applied, it is very useful to use, very practical implemented, is very interesting because it is a new thing.
\end{abstract}

\section{Keywords- parent, engagament, partnership}

\section{INTRODUCTION}

The Government of Indonesia in this case the Ministry of Education Education and Culture through the Directorate General of Early Childhood and Community Education since 2015 has formed the Directorate of Family Education Development. The main task is to strengthen the involvement of families (parents) in supporting children's education in the education unit (school) and at home to support the strengthening of character education (culture) and the culture of children's achievement, increasing understanding, awareness and ability of parents, especially those who still have children school age (under 21 years) to the role and function of the family in educating and caring for children. The task is carried out in stages through a regional / district / city approach.

In 2016, BP-PAUD and Dikmas North Sumatra have developed and tested a model for involving parents in SMP Negeri 2 Sunggal, Deli Serdang Regency with a kinship approach. The results of the development of the model have been validated by the education directorate with several improvements. To improve the partnership model of parents in junior high schools, in 2017 the Partnership model for the State Junior High School in Binjai will be developed again.

As a first step, a preliminary study has been carried out to explore the potential, shortcomings, challenges, and barriers that exist in junior high schools in Binjai city, especially State Middle School 6, State Middle School 9, State Middle School 5 and State Middle School 12 in Binjai City. From the results of exploratory analysis in the four state junior high schools, several facts were found, namely fighting / mixing among children at school, bullying / harassment / violence (physical, verbal, emotional), extortion by senior students to the junior, children have cellphones with pornographic videos, do inappropriate actions in class, students consume drugs/ngelem, students often skip school, are lazy to do homework, pass out because they are not absorbed in the morning, moody /not enthusiastic about learning

The finding of the fact of the field will certainly cause various problems consuming drugs, will damage the brain / health/concentration of children's learning, children's achievement decreases because children often skip class, children are lazy to do homework so that the learning process is disrupted, disrupt order/dangerous, children are bullied/ ridiculed will will be traumatized to school, access to pornography videos damage the brain and concentration of learning, often moody/fantasizing in school will cause concentration, the spirit of learning decreases. Students who are victims of extortion will be afraid to come to school. Often not eating eventually fainting at school will interfere with Learning. The point is all the facts found will cause problems, 
namely disruption of learning comfort and automatic learning objectives not achieved, achievement will decrease.

From the pre-survey results and discussions with stakeholders, the education unit in the Binjai city state junior high school gave rise to the idea of creating and developing a box and a corner of heartbreak (Confidence) to become one of the effective communication media to be developed according to school needs. This makes sense because junior high school students are in transition / adolescents who have the pleasure to confide in their hearts.

\section{LITERATURE REVIEW}

\section{A. Three Educational Center}

The tri-center education partnership is a collaboration between education, family and community units based on the principle of mutual cooperation, equality of position, mutual trust, mutual respect, and willingness to sacrifice in building an educational ecosystem that fosters the character and culture of student achievement.

\section{B. Parent Partnership;}

Theories that support teacher and parent collaboration include:

1) Morisson's theory;

Morisson describes parental involvement as a process by which parents use all their abilities for themselves, their children, and programs run by the child themselves. Parents, children and school programs are part of a process[1].

2) Greenberg's Theory;

According to Greenberg's theory the involvement of parents in school will ease teachers in fostering children's confidence, reducing student discipline problems and increasing children's motivation. Teachers who consider parents to be important spouses or coworkers in children's education will increasingly appreciate and be open to cooperation with parents[2]..

3) Cattermole and Robinson theory

According to this theory the relationship between teachers and parents occurs due to good communication, but parents do not see an interest in overall education but are generally interested in: children's activities at school, their attitude to the tasks given, whether teachers pay attention to their children and others-other. Chattermole \& Robinson[3]. put forward 3 reasons for the importance of effective communication between parents and teachers, namely:

- Teachers must know the needs and expectations of children and parents who attend educational programs

- Parents need clear information about everything that is done by the school, both the program, its implementation and the provisions that apply to the school.

- Good communication will help the implementation of a good educational process. You can see the reciprocal influence of teachers and parents where they want to know the needs of their children.

C. Forms of Parental Engagement in Schools and Homes;
Epstein revealed that there are six forms of partnership with parents, namely: parenting, communication, volunteering, involving parents in children's learning at home, decision making, and collaboration with community groups (Coleman, 2013: 25-27) [4].. The forms of involvement are Parenting, Communication, Parental involvement in children's learning at home, and Decision Making

1) Factors Affecting Parent and School Engagement

Some things that can affect the involvement of parents in schools in terms of the school and parents include:

a) In terms of the school

- The attitude of the teacher. Not many teachers who have the confidence to be able to involve parents in the education system (Patrikakou, 2008: 4). This shows if the teacher does not assume that he is an effective party to provide change

- The teacher's view of parents. The teacher also reports that single parents who are indicated to spend more time accompanying their children to study at home are not necessarily sufficiently involved in their children's education at home (Patrikakou, 2008: 4). [5].

- A lot of things to do but a little time.

b) In terms of parents:

- Lack of Information. The main thing in parental involvement is communication between parents and the teacher. Notification of information about children's education can be through a contact book for example (Patrikakou, 2008: 4).

- Life demands. Time is the main thing that inhibits the involvement of parents in school or accompanying children to learn at home. Parents find it difficult to arrange the right time to be involved in children's education.

- School environment. Children come from various families who have different experiences, such as coming from poor families and in daily activities lacking interaction with family, school or community. This will make them misunderstand and worry about the school environment (Patrikakou, 2008: 4).

\section{Internal and external factors}

Internal factors (factors that are in the student themselves), among others:

- Physical disorders, such as lack of functioning of the sense organs, speech, sensory disorders, bodily disabilities, and restraining diseases (allergies, asthma, etc.).

- Mental imbalance (a disturbance in mental function), such as showing a lack of mental ability, the level of intelligence tends to be lacking.

- Emotional weaknesses, such as feeling insecure, maladjustment, gripping with fear, hate and antipathy and emotional immaturity. 
- Weaknesses caused by wrong habits and attitudes, such as lack of attention and interest in school lessons, laziness in learning, and often skipping class or not attending classes.

External factors (factors that arise from outside the individual), that comes from

- School, including: the nature of the curriculum is less flexible; too heavy the burden of learning (students) and or teaching (teacher);Inadequate teaching methods; lacking of tools and resources for learning activities

- Family (home), including: the family is not intact or less harmonious; attitudes of parents who do not pay attention to their children's education; economic situation;

\section{F. Confidence Box;}

The vent box in question is the availability and usefulness of glass boxes that are hung in each class as a means / place to accommodate the outpouring of each student's heart which disrupts the comfort of learning.

- If you experience emotional intimidation (insults, derogatory comments, changing your nickname and teasing) will tell the teacher / BK (councelling) teacher / homeroom / parent;

- If you experience physical intimidation (pushing, grabbing, hitting, fighting and spitting) will tell the teacher / BK teacher / homeroom / parent;

- If there is pornography and porno-action, it will tell a teacher / BK teacher / homeroom / parent;

- If there is sexual harassment both from within and from outside will tell the teacher / BK teacher / homeroom teacher / Parents;

- If there is a sense of ethnic sentiment, racial religion between groups will tell the teacher / BK teacher / homeroom teacher / Parents;

- If you experience blackmail both from inside the school and outside the school, you will tell the teacher / BK teacher / homeroom teacher / Parents;

- Students have freedom (there are written means if reluctant) to complain / convey personal / emotional / social problems in school;

- Parents have freedom (there is a written tool if they are reluctant) to complain / convey the child's personal / emotional / social problems at school;

- The teacher / counselor / homeroom teacher cares about students' personal / emotional / social problems;

- Students are not afraid if they meet with a teacher / counselor / homeroom teacher;

Corner vent is the availability and usefulness of the corner to vent comfortably as a means of accommodating personal, emocional and social problems as well as a place to provide psychological support for every school citizen;The Parenting Partnership Strategy through the Box and the Confident Corner can be illustrated in Fig.1.

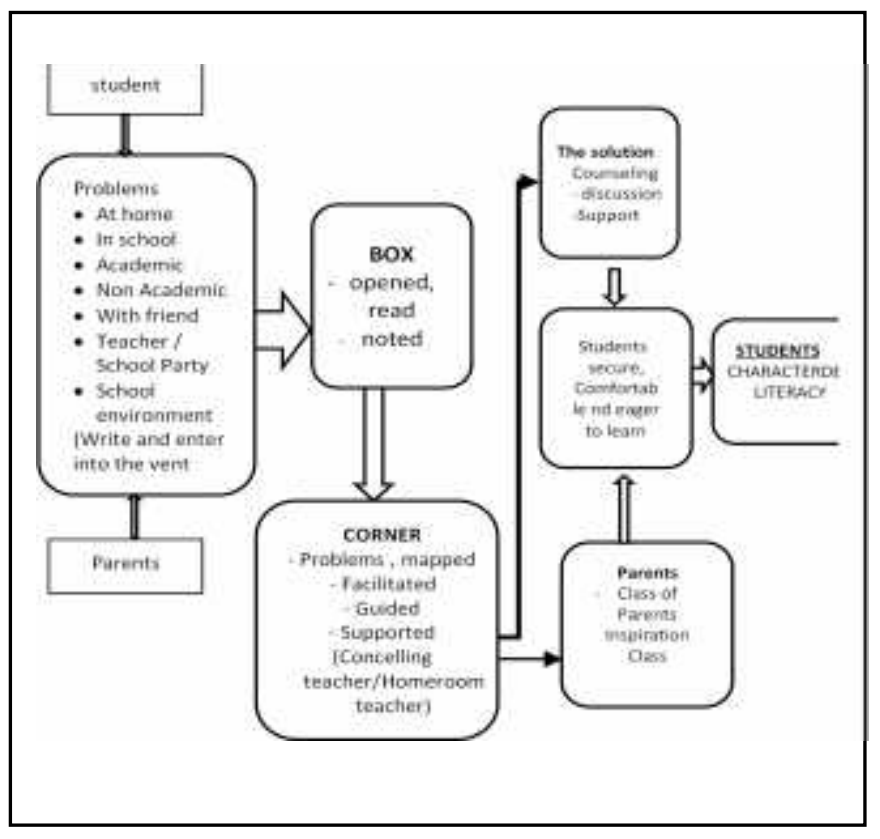

Fig 1. Parent Partnership Through Boxes and Confide Corner Models

\section{METHODOLOGY}

The development of the Parent Partnership model is carried out through the Research and Development (R \& D) approach that is followed by the stages; 1) Preliminary Study, 2) Literature Study, 3) Draft Modeling, 4) Conceptual Model Validation, 5) Conceptual Model Trials; a) Preparation, b) Implementation, c) End of activities, 6) Documenting the results of limited trials, 7) Testing of Operational Models, 8) Report Writing, 9) Standardization of Models; a) Dissemination and Implementation, b) Replication[6].

To determine the effectiveness of the measurement model for the achievement of variable indicators, a Likert scale instrument with 5 scales is used, while for the implementation or practicality in applying the model, it uses observation guidance instruments and a Likert scale instrument with 4 scales. Data Analysis Techniques The trials in this study were carried out with a pre and post test design. Furthermore, to measure effectiveness, implementation or practicality and attractiveness, t-tests and data processing and analysis are performed using the spss stastisc 2.2 software application.

\section{RESULTS AND DISCUSSION}

\section{A. Result}

The exploration was carried out from the 15 th to the 22 nd February 2017. Exploration studies were carried out in 4 junior high schools in Binjai City, namely SMP Negeri 6 Binjai City, SMP Negeri 9 Binjai City, SMP Negeri 5 Binjai City and SMP Negeri 12 Binjai City. The results of the analysis of exploratory activities show several problems, one of which is the lack of supporting facilities for the implementation of parental involvement in schools, such as 
the absence of special spaces for parents to express their aspirations, making parents reluctant to come to school Field Trial Results (Experimental Variable Data Description)

The results of the implementation of operational trials in accordance with the instruments used can be described in the following table:

TABLE 1. DISTRIBUTION OF DATA FREQUENCY EXPERIMENTAL

\begin{tabular}{|c|c|c|c|c|c|c|c|c|}
\hline \multicolumn{9}{|c|}{ VARIABLES (PRE AND POST) } \\
\hline & $\begin{array}{c}\text { A } \\
\text { (pre) }\end{array}$ & $\begin{array}{c}\mathrm{B} \\
\text { (post) }\end{array}$ & $\begin{array}{c}\mathrm{C} \\
\text { (pre) }\end{array}$ & $\begin{array}{c}\mathrm{D} \\
\text { (post) }\end{array}$ & $\begin{array}{c}\mathrm{E} \\
\text { (pre) }\end{array}$ & $\begin{array}{c}\mathrm{F} \\
\text { (post) }\end{array}$ & $\begin{array}{c}\mathrm{G} \\
\text { (pre) }\end{array}$ & \begin{tabular}{|c|}
$\mathrm{H}$ \\
(post)
\end{tabular} \\
\hline NValid & 60 & 60 & 60 & 60 & 60 & 60 & 60 & 60 \\
\hline Missing & 0 & 0 & 0 & 0 & 0 & 0 & 0 & 0 \\
\hline Mean & 3.52 & 4.42 & 2.82 & 4.25 & 2.75 & 4.02 & 3.13 & 4.27 \\
\hline $\begin{array}{l}\text { Std. Error } \\
\text { of Mean }\end{array}$ & .087 & .064 & .113 & .056 & .125 & .065 & .077 & 103 \\
\hline Median & 3.00 & 4.00 & 3.00 & 4.00 & 2.50 & 4.00 & 3.00 & 4.00 \\
\hline Mode & 3 & 4 & 2 & 4 & 2 & 4 & 3 & $4^{\mathrm{a}}$ \\
\hline $\begin{array}{l}\text { Std. } \\
\text { Deviation }\end{array}$ & .676 & .497 & .873 & .437 & .968 & .504 & .596 & .800 \\
\hline Variance & .457 & .247 & .762 & .191 & .936 & .254 & .355 & 640 \\
\hline Skewness & .958 & .347 & .372 & 1.185 & .646 & -1.610 & 1.451 & -1.348 \\
\hline $\begin{array}{l}\text { Std. Error } \\
\text { of } \\
\text { Skewness }\end{array}$ & .309 & .309 & .309 & .309 & .309 & 309 & .309 & 309 \\
\hline Kurtosis & -.236 & -1.946 & -1.603 & -.619 & -.347 & 8.409 & 3.761 & 3.243 \\
\hline $\begin{array}{l}\text { std. Error } \\
\text { of } \\
\text { Kurtosis }\end{array}$ & .608 & .608 & .608 & 608 & .608 & 608 & .608 & 608 \\
\hline
\end{tabular}

Source: Data Processing using SPSS

Explanations:

A, B : Principal's Commitment

C, D : Commitment of School Principals

E, F : Parent Co-operation in School

G, H : Availability of Parent Cooperation in Schools

2) Model Effectiveness Test

\section{TABLE 2. TEST T STATISTICS}

\begin{tabular}{|c|c|c|c|c|c|}
\hline & $\mathrm{M}$ & $\mathrm{N}$ & SD & SDm \\
\hline \multirow[t]{2}{*}{ Pair 1} & Principal's Commitment Pre & 3.52 & 60 & .676 & .087 \\
\hline & Post & 4.42 & 60 & .497 & .064 \\
\hline \multirow[t]{2}{*}{ Pair 2} & $\begin{array}{l}\text { Teacher / Homeroom } \\
\text { Teacher Support Pre }\end{array}$ & 3.13 & 60 & .596 & .077 \\
\hline & Post & 4.27 & 60 & .800 & .103 \\
\hline \multirow[t]{2}{*}{ Pair 3} & $\begin{array}{l}\text { Willingness for Parent } \\
\text { Cooperation in Schools Pre }\end{array}$ & 2.82 & 60 & .873 & .113 \\
\hline & Post & 4.25 & 60 & .437 & .056 \\
\hline \multirow[t]{2}{*}{ Pair 4} & $\begin{array}{l}\text { Parental Support } \\
\text { Implementation at Home Pre }\end{array}$ & 2.75 & 60 & .968 & .125 \\
\hline & Post & 4.02 & 60 & .504 & .065 \\
\hline \multirow[t]{2}{*}{ Pair 5} & Benefits of Confide Box Pre & 1.87 & 60 & .343 & .044 \\
\hline & $\begin{array}{l}\text { Benefits of Confide Box } \\
\text { Post }\end{array}$ & 4.32 & 60 & .676 & .087 \\
\hline \multirow[t]{2}{*}{ Pair 6} & $\begin{array}{l}\text { Benefits of Confide Corner } \\
\text { Pre }\end{array}$ & 2.18 & 60 & .390 & .050 \\
\hline & $\begin{array}{l}\text { Benefits of Confide Corner } \\
\text { Post }\end{array}$ & 4.37 & 60 & .688 & .089 \\
\hline \multirow{4}{*}{$\begin{array}{l}\text { Pair } 7 \\
\text { Pair } 8\end{array}$} & Learning comfort Pre & 2.82 & 60 & .770 & .099 \\
\hline & Learning comfort Post & 3.97 & 60 & 486 & .063 \\
\hline & $\begin{array}{l}\text { Parent Partnership Follow } \\
\text { Up Pre }\end{array}$ & 1.82 & 60 & .725 & .094 \\
\hline & $\begin{array}{l}\text { Parent Partnership Follow } \\
\text { Up Post }\end{array}$ & 4.43 & 60 & 5.251 & 678 \\
\hline
\end{tabular}

TABLE 3. PARENT PARTNERSHIP MODEL THROUGH BOXES AND CONFIDENT CORNER

\begin{tabular}{|c|c|c|c|c|c|c|c|c|c|}
\hline \multirow[b]{2}{*}{ No } & \multirow{2}{*}{$\begin{array}{c}\text { Model } \\
\text { Specificatio } \\
\text { ns }\end{array}$} & \multicolumn{8}{|c|}{ Level of implementation } \\
\hline & & $\mathrm{ST}$ & $\%$ & $\mathrm{~T}$ & $\%$ & KT & $\%$ & TT & $\%$ \\
\hline 1 & $\begin{array}{l}\text { Principal's } \\
\text { policy }\end{array}$ & 3 & 100 & 0 & 0 & 0 & 0 & 0 & 0 \\
\hline 2 & $\begin{array}{l}\text { Parental } \\
\text { involvement } \\
\text { in school }\end{array}$ & 48 & 80 & 0 & 0 & 12 & 20 & 0 & 0 \\
\hline 3 & $\begin{array}{l}\text { Parental } \\
\text { support }\end{array}$ & 48 & 80 & 0 & 0 & 12 & 20 & 0 & 0 \\
\hline 4 & $\begin{array}{l}\text { Teacher / } \\
\text { homeroom } \\
\text { support }\end{array}$ & 20 & 80 & 0 & 0 & 4 & 20 & 0 & 0 \\
\hline 5 & Vent box & 25 & 100 & 0 & 0 & 0 & 0 & 0 & 0 \\
\hline 6 & $\begin{array}{l}\text { Confide } \\
\text { Corner }\end{array}$ & 3 & 100 & 0 & 0 & 0 & 0 & 0 & 0 \\
\hline 7 & $\begin{array}{l}\text { Oriented } \\
\text { student } \\
\text { learning } \\
\text { comfort }\end{array}$ & 28 & 100 & 0 & 0 & 0 & 0 & 0 & 0 \\
\hline 8 & $\begin{array}{c}\text { Continuous } \\
\text { evaluation }\end{array}$ & 3 & 100 & 0 & 0 & 0 & 0 & 0 & 0 \\
\hline
\end{tabular}

Remarks: $\mathrm{ST}=$ very well done $\mathrm{T}=$ done $\mathrm{KT}=$ less accomplished $\mathrm{TT}=$ no

Table 1. illustrates that of the 3 school principals observed regarding the commitment of parent partnerships in school, the principal's policy was very much implemented $100 \%$, parental involvement was very much carried out $80 \%$ not implemented $20 \%$, parental support was very much implemented $80 \%$ less implemented $12 \%$, the utilization of the vent box was very much carried out $100 \%$, the use of corners ventured very $100 \%$, the use of boxes and corners ventured $100 \%$ oriented to the comfort of student learning, continuous evaluation in 3 schools was very $100 \%$ implemented.

\section{B. Discussion}

From the test results clearly illustrated that there are significant differences in values between the values before treatment and after treatment. There is an increase in the commitment of the principal after the trial, the support of the teacher / teacher BK / Homeroom teacher, support of parents at school, support of parents at home, available and the use of a vent box so that the problem of children both personal / social / emotional is accommodated, available and utilized confide corner (children both personal / social / emotional problems have been followed up, increase learning comfort, increase partnership follow-up. From the effectiveness test it was proven that the parent partnership model in Binjai City Junior High School through the box and vent corner. Effective in the sense of the expected goals in the model can be reached.

In table 1 illustrated that from 3 principals observed regarding parent partnership commitments in school the principal's policy was implemented $100 \%$, parental involvement was carried out $80 \%$ not implemented $20 \%$, support for BK teachers / homeroom teachers $100 \%$, support $80 \%$ of parents are very accomplished less $12 \%$ implemented, the use of confide boxes is very carried out $100 \%$, the utilization of confide corners is done $100 \%$, the use of boxes 
and confectionary corners are $100 \%$ oriented towards student learning comfort and continuous evaluation in 3 schools is very $100 \%$ carried out. So that the implementation of the partnership model of parents in the binjai city state junior high school through boxes and corner confides had an average implementation of $97 \%$. This means that all teachers who participate in the implementation of the program are very easy to implement the model.

The success factor in implementing / implementing the partnership of parents in junior high school through ventilation boxes and corners is due to the existence of clear main concepts and must be understood by the implementers in the field as outlined in the practical guide book that does not interfere with the main field activities, implementation carried out by managers and implementers (BK teachers / homeroom teachers) do not deviate from the job descriptions of the implementers daily. Because the partnership of parents through boxes and ventilation is carried out in the first secondary school whose main task is to provide education to children, counseling to children, requires support / cooperation of parents in educating children. All can be synergized with program adjustments and location facilitation and infrastructure.

The dimensions or determinants of the success of the model are easily identified. Model specifications are:

- There is a policy / commitment from the principal that is consistent and implemented;

- The support of the teacher / teacher / homeroom teacher in applying the partnership model of parents in junior high school shows concern for each child's personal social problems (reading a child's outpouring, mapping, and following up through psychological support or completing it on a vent);

- The involvement of parents in the school is the parents' willingness to work together and the participation / attendance that is consistent in each partnership activity starting from the first day of school, parent class, inspiration class and year-end class performances;

- Parental support at home is to apply good habits at home as written on the family support card and set an example for children;

- Confide box as a means of accommodating all children's problems both psychological and social problems that make learning uncomfortable and applies to all students;
- Confide Corner as a comfortable place for someone to receive psychological support from the teacher or from parents

- Oriented to the convenience of learning, the model seeks to provide solutions to each problem until the child is truly comfortable to learn;

- Ongoing evaluation, all problems will be analyzed and then submitted to the parents' association to be followed up on the parent class or the inspirational class.

\section{CONCLUSION}

From data analysis and discussion of Model trials, some conclusions can be drawn as follows:

- Output (output) Partnership Model Parents through boxes and Confident Corer can be the comfort of student learning;

- The Parent Partnership Model in junior high schools through boxes and confide corners is effective in increasing increasing student learning comfort and increasing parental support for the implementation of family education both at home and at school;

- Response of managers (school principals, teachers / homeroom teachers / BK teachers) as users of the Parent Partnership Model through the Box and Confession Corner: very important to apply, very useful to use, very practical to implement, very interesting because it is new;

\section{REFERENCES}

[1] Morrison, G. S. (1988). Education and development of infants, todlers and preschoolers. USA: Scott, Foresman and Company.

[2] Arsmden, G. C., McCauley, E., Greenberg, M.T., Burke, P. M., dan Mitchell, J.R. (1990). Parent and peer attachment in early adolescent depression. Journal of Abnormal Child Psychology, 18 (6), 683-697

[3] Cattermole, Juleen; Robinson, Norman, Effective Home/School Communication--From the Parents' Perspective. Phi Delta Kappan, v67 n1 p48-50 Sep 1985

[4] Coleman, M. 2013.Empowering Family-Teacher Partnership Building Connections within Diverse Communities. Los Angeles: Sage Publication,Oktavian, Arul, 2

[5] Patrikakou, E. N. 2008. The Power of Parent Involvement: Evidence, Ideas, and Tools for Student Success . Diakses pada tanggal 12 Juni 2017

[6] Sugiyono, 2017. Metode Penelitian Kuantitatif, Kualitatif dan R \& D, Jakarta, Alfabeta 